\title{
Intelligent Agent Based Architectures for E-Learning System: Survey
}

\author{
Muhammad Arif $^{1,3}$ and Mehdi Hussain ${ }^{1,2}$, \\ ${ }^{1}$ Faculty of Computer Science and Information Technology, University of Malaya \\ 50603 Kuala Lumpur, Malaysia \\ ${ }^{2}$ School of Electrical Engineering and Computer Science, National University of \\ Sciences and Technology, Islamabad Pakistan \\ ${ }^{3}$ Computer Science Department, Comsats Institute of Information and Technology \\ Islamabad Pakistan
}

\begin{abstract}
E-learning is the internet enabled learning. Internet has ongoing to restructuring education. Intelligent agent based e-learning provide a common infrastructure to assimilate varied software components. There are two sorts of e-learning synchronous and asynchronous. This paper described the detail of well-known agent based architecture for e-learning. E-learning is going to be gigantic. There are multiple benefits of e-learning; it is convenient, self-service mix, match, on demand any time anyplace, private learning, Self-paced and elastic. E-learning provide cost effective and virtual environment. E-learning gives the ability to user to collect the quantifiable and sensible material, examine, and distribute and custom e-learning knowledge from multiple $e$ learning sources.
\end{abstract}

Keywords: E-learning, Multi Agents, Architecture, Ontology, Collaborative, Personalized, Intelligent, Agent-Grid, adaptive, Distributed, Interoperable, web service

\section{Introduction}

Agent technology is involved in many fields. Agents have the ability to make decisions at their own hands and this technology is very good and fast then objects oriented technology. They can share with each other without knowing the address of other agent or methods of other agent. Now a day's web base agent research is the main focus and interoperation of agents in different environments (heterogeneous). E-learning is the new environment for learning. In e learning there is need to implement new technologies and approaches to meet the requirement. There are several types of learning like vocational education, e learning and vocational e learning. The vocational education is a skilled based education and e learning is technology enabled learning. Vocational e earning is a skilled based and technology based e learning. The goal of e learning is to acquire tool for survival and also discover the meaning and to enhance the security equality. Essentially the e learning means that to deliver large amount of knowledge to enhance performance through distance based education. In other words the e learning is the internet enabled learning. Internet has ongoing to restructuring education. The outdated classrooms have to be transferred. Only $1 \%$ of the population taken online course e learning is still new. There is need to enhance thee learning through different techniques like data mining, statistics, machine learning and many more. E learning is going to be gigantic. There are multiple benefits of e learning e-learning is convenient self-service mix and match, on demand any time anyplace, this is a private learning Self-paced and elastic cost effective virtual environment, Share lesson among school colleges and universities. And reduce material cost, reduce travel accommodation. 


\section{Service Oriented Architectures for Agent Based E-Learning Systems}

(1) Collaborative e learning using multi agent

(2) Multi agent architecture for intelligent e learning,

(3) Service Based Oriented Intelligent Agents for E-Learning Systems,

(4) Domain Ontology for Personalized Multi-agent E-Learning Systems.

\section{Collaborative E-Learning Using Multi Agent}

The proposed architecture [12] has three levels: User Interface Layer, Learning Services Layer and Infrastructure Layer. User interface layer delivers interface to user to access all types of source and learning material. Jade is used for multivalent system implementation. The Learning Services layer contains all resources and services components. The Infrastructure Layer offers the underlying services that can support the data exchange and transmission. The ELMS is contains of three players learner, instructor and teacher. The learner aim is to learn by questioning, reading data, taking quiz and exercise.

The instructor aim to teach online by managing and arranging seminar and he can guide student which subject he should choose. A virtual collaborative group is constructed of small containers and one main container which control all other containers. Each container contains many learners and instructor agents. When the user wants some information about course student agent sends request instructor agent that will guide the learner after checking its evaluation.

Agents are used in the field of e-learning for the ease of user learning [15, 39]. MultiAgent System for Collaborative E-learning (MASCE) is introduced which helps teaching and learning process and support collaborative learning among peers. Multi agent can intelligent interact with each other to support the educational processes. System has three agents: student agent and teacher agent with respect to its users. Student agent helps student in learning process. Instructor agent maintains course progress, avail course material and checks course progress. Assistant agent which is the basic advancement in architecture is placed on the system's server. It acts more effectively between end units.

Educational is divided into sub-divided into categories till leave node. Student can check out their performance by taking their own quiz [15]. Agents are used in the field of e-learning for the ease of user learning. Multi-Agent System for Collaborative E-learning (MASCE) is introduced which helps teaching and learning process and support collaborative learning among peers. Multi agent can intelligent interact with each other to support the educational processes. System has three agents: student agent and teacher agent with respect to its users. Student agent helps student in learning process. Instructor agent maintains course progress, avail course material and checks course progress. Assistant agent which is the basic advancement in architecture is placed on the system's server. It acts more effectively between end units [33].

Educational is divided into sub-divided into categories till leave node. Student can check out their performance by taking their own quiz. Assistant agent helps them if material regarding to any topic is required. System contains static as well as dynamic parameters. Static parameter information is provided by the student while dynamic parameter information is gained from student colleague at end of each session [33].

The main consideration of this paper is complication of E-Learning system. Mutual learning grouping of multi-agent is controlled. Rough set theory is combined with mutual learning grouping for solving problem of information absence [34]. Full information theory for grouping model and algorithm is designed. The architecture is implemented into the frame of NJUT ELearning to fulfill the requirements. [36] The study has been conducted on six emotions of human defined by Ekman which are as: happiness, surprise, anger, fear, sadness, disgust. Interface agent provides learner information to other agents. Emotional embodied conversational agent contains three layers. First layer perceives 
facial expression and classify it. Second layer analyze learner emotional state and third layer takes corresponding actions. Emotional agent specifies the state which learner has by calculating parameters. Curriculum agent keeps the record of learner activities [34]. Tutoring agent keeps record of teacher. Implementation is done EMASPEL Framework with the Mad Kit Platform. An open source p2p network is built JXTA Framework (Gong 2002) to build.

\section{Multi Agent Architecture for Intelligent E-Learning}

Four layers existing in this model, namely Interface Layer, Middle Layer, Database Controller Layer and Database Layer. Interface controller service is used to communicating between interface layer and middle layer. This service gets request from interface layer and if it is validation request send it to middle layer, after prepare the proper response in middle layer, this service send response to interface layer. Connection service is used to communicating between middle layer and DB controller layer [3]. This service gets request from multi agent systems in middle layer and if it is validation request send it to respective agent in DB controller layer, after prepare the proper response in DB controller layer, this service send response to middle layer. Data access service is used to communicating between DB controller layer and DB layer. Data access service manage access (insert, select, update and delete) to databases [3]. In a client server model, for any services client is depends on server. In mobile agent if client needs any service then it goes to server and after completion of service it comes back. Agent can learn, proactive, and social. Mobile Agents have two parts one is its coding part and the other is the current execution state. Server-client security, agent movement and same working environment are key points while constructing a mobile agent system.

The main functions of agent are as it should be social, contains educational data and consider each individual requirement and cross interacts asynchronously [11]. The proposed architecture contains five agents: interface agent, learning agent, teaching agent, mobile agent, agent server and interface agent. Architecture of a mobile agent has data structure, function, status, knowledge and interface. Agent server provides a standard interaction interface with maintenance of agents. Teaching adopts effective methods and finds out course material via course management agent. Learning agent is one provide them interaction with e-learning system. Agent movement is carried out through agent serialization; transfer over network and de-serialization. Thus mobile agent takes less time for communication than client-server model [11]. One of the important challenges in elearning is the user understanding. The proposed Intelligent Learning Environment architecture mainly focuses on user learning requirement. User can access the system via a specialized web browsing server and provide a special agent to each user. Learner personal assistant provides Automatic Tutoring and the Student Evaluation, learning item authoring and test tools. Learners profile contains three main modules Learning Objective (LO), Learning Modality (LM) and Knowledge Watch (KW). The learning process needs are determined by LO which are more précised in LM. The $\mathrm{KW}$ offers the active adaptableness of the student performance material. The architecture is implemented on several courses and the acceptance of system was high [14]. Implementation of multiagent system is done through NEOCAMPS2.The initial architecture of e- learning consists of different units: a) Mental state unit, b) agent control system unit in which task knowledge and decision both have fuzzy, c) perception unit d) communication unit e) the task knowledge unit f) planning and learning modules. Main three types of agent architecture consist are supervisor, sub-tutors and interface agent. Supervisor agent has student learning style, sub-tutor activities. Sub-tutor agent check student's mistakes and provide them correct knowledge. Interface agent keeps and maintain record of students. System is evaluated by applying in medical center. Thus multi agents are capable to learn and give very good results [14]. The main emphasis in this paper is self-learning through 
e learning system which is an open intelligent and integrated system based on data organization in data warehouse. System is composed of six module related to e-learning, as synchronous learning module, asynchronous learning module, evaluation module, information service module, resource management module [25]. In data organization the system consist of three main parts. E learning system resource database, Model database and knowledge database, and the learning resource database [25].

[26]Paper provides a common agent based architecture for e learning which provide features like intelligence, distributed, and collaborative and extensible in a single architecture. System is considered to be a successful system in regard of e learning by giving efficient performance. Through the above mentioned features system enhances the quality of learning. The multi-agent technology is implemented for the collaboration and safe resource sharing among distributed individuals and institutions, and the different ELearning systems. E-Learning system aims to provide better output, access and understanding to learners [29].

The integration of E-Learning should be secure, dynamic and includes sub functions. The main tasks of information integration: coordination of the system sub functions, decision making via study and interaction of user with system. The architecture contains following agents: local resource, management, integration and user agents. Local resource agent forwards request to integration agent made by other agents. Management agent provides material to integration agent. When information from other agent is collected it is returned to local agent. The basic technologies of integration system platform include Simple Object Access Protocol, Extensible Markup Language and intelligent Agent. Simple Object Access Protocol and XML provide communication protocol among multi agents which can learn [30]. The proposed e-learning system has three layers: The user level, the application level and the storage level. There are two main players. One is the learner who learns either individually or cooperatively. They work in group to achieve same task. Second is the teacher who teaches and assists student by answering their queries. Prometheus methodology is applied to achieve agent-based environment according to which each item should be consistent and union. As teacher has a lot duty agents will help him for user interaction, learner queries, group creation and so on. JACK platform is used [30]. The main issue is Description and interest of learning objects. To handle this issue hierarchical structure multi-agents' platform is used. Local core and remote parts integrated with LO repositories are e-learning platform components. The basic function is storing, managing and finding the data. Metadata and users accounts databases are key databases [37].

Data collection in local database is done by three agents. Content Manager Agent manages the collector agent for LMS and communicates with remote objects. Converter agent converts the data into format available for fast search. Search module is performed by multi-agents based on different algorithms. One agent is assigned to each user. When the user is working agent its alive otherwise it becomes dead. Personal agent requests for search and find result [37].

In this paper [27] challenge of personalized and inclusive e learning scenarios have been addressed. They have been designed a recommendations model and a multi-agent architecture to manage what, when, how and why by offering recommendations to users in their scenarios. According to the approach for dynamically supporting learners during the course execution draws two levels multi-agent architecture in lower level and high level. The lower level called ADA+ and high level is A2M. ADA+ is implemented as ADAPTA plan project and A2M is as recommendation system in charge of offering recommendation to users [27].

In [17] proposed architecture has agent for each subject is specific including expression extraction and user interface using ACM CR classification hierarchy. Concept dictionary contains a list of concepts. When a user searches for a phrase, an agent phrase agent performs some preprocessing and searches by comparing with concept dictionary in the 
system. For every subject a specific agent is planned. The concept evaluation and recognition of related documents to the user-query are maintained. At the advent of the new question, the subject-specific agents become vigorous and carry out the concept relativity analysis. User-Interface Agent offers a variety of services to learn about the user. These services are Login system, Search display, Concept Dictionary, Document suggestion window, User-Interaction Window and Help window. Blackboard accumulates and interchanges the query and messages mandatory for different servers. Dispatcher checks and informs the entire agents about the new query in the black board. Latent Semantic Analysis along with concept matrix setup facilitates one to retrieve related concepts effectively even if user given phrase is not accessible.

In [23] paper the author introduced extension to MASHA (multi agent system handling adaptively) to MASHA-EL (multi agent system handling adaptive e learning). In this system students or users which use different devices for such purpose are provide with a device agent and each learning website with a teacher agent. Considering the exploited device provides useful recommendations. MASHA-EL partitioned the students into clusters and graphs of students of same profile and each cluster is provided with a tutor agent which manages the student according to their profile [1].

In [6] paper the author introduced asynchronous web based training system has been developed using client server model. The scalability and robustness problem of client server environment has been removed in decentralized manner using $\mathrm{P} 2 \mathrm{P}$ technology and mobile agent technology all contents and functions which are used for users awareness are placed on mobile agents and these mobile agents are distributed to computers. Here the two backup recovery schemes have been developed for the mentioned distributed e learning system. According to these scheme which our nodes becomes failure then another node continuous giving services using backup of agents belong to failure node. In the system failure of one node can be tolerated also can tolerate failure of more than one node under the condition that if the failure of organized backup node do not occur at the same time.

This paper [8] is about assessment of student learning that how much he has learnt and how can make more improvements in student learning. There are major components of e assessment named e-test and e-portfolio. This specifies some criterions which help identifying that the learner at other ends in learning well/bad. There are three kinds of assessments named

1- Pre-Assessment

2- Summative Assessment

3- Formative Assessment.

Question and Test Interoperability 'QTI' helps sharing the assessment items in common format. CAT is using the iterative algorithm and this evaluates the user ability level. This uses the prior answers for judging the ability level and repeats itself until termination criteria meets. CCT and same as CAT the difference is only termination criterion. Cat works best for formative assessment CCT works best for summative assessment. The learner different skills are stored in e Portfolio that helps making engine more intelligent. The learner experience can be get by thinking style and then can update in the system for making improvements in the system. There is a bank of different items question and a threshold value if the user pass a certain test then he will move to next test otherwise remains at same level also the test level will be automatically updated by assessing the learner poor/good performance. Formative and summative assessments help here in understanding the learner learning ability. Web mining is also used here for enhancing student abilities of learning and this is done here by student navigational behavior.

This paper [19] presents an intelligent approach for implementing the web-based ELearning and tutoring. Architecture \& Design: Poly-X mainly consists of four subsystems, which are: 
(1) Intelligent Quiz System for learning outcome assessment

(2) Presentation System for teaching, sharing and presentation

(3) Video Conference System

(4) Discussion System

Poly-X contains concepts, short notes, videos, demos, possible sources, animations, graphics, case studies, etc. In online discussion: (1) Video Conference (2) Online White Board (3) PowerPoint Presentation will be managed. In Statistical and Analysis Model actions of the user will be recorded in the system and by using this feature it is possible to find the number of students interested in particular subject. System can record the name of user, difficulty level and answer. This is very helpful information in predicting student level and problems which are faced by students. When students login they will be connected to server automatically then quizzes can be managed to assess the individual student understanding level with the system and at the end of quiz the results can be shown to student. Student can view the correct answers and wrong answers as well and description of the wrong answers also.

The multi-agent technology is implemented for the collaboration and safe resource sharing among distributed individuals and institutions, and the different E-Learning systems. E-Learning system aims to provide better output, access and understanding to learners [10].

The integration of E-Learning should be secure, dynamic and includes sub functions. The main tasks of information integration: coordination of the system sub functions, decision making via study and interaction of user with system. The architecture contains following agents: local resource, management, integration and user agents. Local resource agent forwards request to integration agent made by other agents. Management agent provides material to integration agent. When information from other agent is collected it is returned to local agent [10]. The basic technologies of integration system platform include Simple Object Access Protocol, Extensible Markup Language and intelligent Agent. Simple Object Access Protocol and XML provide communication protocol among multi agents which can learn. The system is build using agent-based concept and aims at Learning, Internet-based course content, and a bidding game system. Student and teacher data and activities are managed [35]. The Learning Space center plays as a platform to convey basic virtual classroom functionalities. Bidding game is introduced to maintain interest of students in which they make a virtual factory by minimizing costs. The discussion section provides information and education. Thus internet based system provides students to learn course [35].

Agent base information system provides direct instructions or feed back to the students without intervention of human beings. ABIS provides personnel assistance to learner. Propose the addition of intelligent applications to the ABIS [4]. When multiple e discussions occurs simultaneously then to direct the teacher's attention to the 'hot spots,' this paper proposes software tools that pre-process, aggregate, and summarize the incoming flood of data. When two or more questions are same then an information retrieval system will check the questions and give the answers to all of these questions. Recommended engine would help the user when he or she studying a particular topic then related links will be provided. Educational Engine will help in identifying assignments material copy and quizzes questions and answers. Mining techniques will help here in quizzes, assignments.

Agents are used to perform some action instead of user and each user is assisted by an agent and the personnel agent will provide its users the web page or related data according to the search topic searching by the user. The intelligent agent will help to obtain the optimized search results which are preserved in digital library. This paper shows the modeling and simulation come close to for the research of various process of e learning system concerning to feedback and multi-agents. Simulations concentrate on the 
importance of intelligent agent's self-sufficiency on the basis of feedback analysis. More than a few processes are tested to find out most well-organized process [28].

Agents are goal based [13]. The goals should be precise, quantifiable, practical and attractive. The goal description is an important element for conceptual modeling, investigation and assessment of the goals of agents. A model contains four parts: arc, state, transactions and tokens. State represent objective which agent aim to, it can be blank or shadowed. Transitions are connections through which various states are linked. Arc is connector for state to transition and vice versa. Token represents changed performance of agent [13]. Service-based grid contains only e-learning agents: marketing agent and service agent. Marketing agent interacts with service agent who in turn interacts with service provider and consumers. For both agents negotiation composite state is subdivided by using multi-agent approach [13].

A proof-of-concept agent mediated grid system prototype has been introduced. It contains four nodes which are front end, information service and course management respectively. Node 1 is for interface, records are stored in node 2. Node 3 and 4 provide course management systems. Thus composite goal model is used to model recognize, obtain, categorize and organize multi-agent systems in the complex grid environment [13]. For E-Learning issues Grids are increasingly are in use. Regionally Distributed Architecture for Dynamic e-Learning Environment architecture implemented by using JADE [31]. Agents assure independence, communication, and consistency in the system. Agents becomes active when user requests and response [38]. Service oriented approach to the design of an e-learning collaborative environment with virtual organization has three communities each representing a level: community of instructional resources, agents and learning resources. The proposed system regards environment as a foundation of resources and the two basic are learning resources and instructional resources [38].

These are used by learners and instructors. The synchronization of resource distribution is a network problem. The e-learning environment consists of two grid layers. One is Instructional resources, second is the learning resources. The incorporation of agents is required by the instructor for the manufacture of learning resources [38].

\section{Service Based Oriented Intelligent Agents for E-Learning Systems}

Paper proposes a novel architecture for e learning system which is based on web service intelligent agents. Using the web service and intelligent agents the e learning becomes the integrated, flexible, intelligent personalized and light weight system. By using the web service technology system can be loosely coupled and can be distributed over the internet. Intelligent agent technology can be used for special learning needs of particular users and learning context can be intelligently customized according to requirement of particular uses. In the purposed system web services plus intelligent agent's technologies are interrelated with each other to get good results for e learning [20]. SOAE [9] consists of a user agent which is submitting query to the system then a query analyzer agent will receive the query and perform operations at the query. This will find out the keywords from the query and query analyzer passes this query to then selected agent. This process goes to further next steps and after user decide the service the composition agent invoke the service and return results to the user. GUI plays the role of middleware for query purposes by the end user. GUI is further divided into 5 steps. Text field for user query, a dropdown list of available services, a popup menu of available services, then a composition agent which give response of user query and a result displaying text box. Query analyzer takes the query and uses the TFIDF to rank the result of query. It's an indexing scheme which will find our keyword in registries [9].

QQA module "The query is input to the stemmer that removes stop words from it. The stemmed query that is filtered down to potential service keywords is passed to the QAA. The agents in the referral system continuously update the Agent vector repository. Each 
agent is responsible for an agent vector. It does a search on the registry that it is associated to. Based on the keywords found it updates the agent vector according to the TFIDF approach described above. The QAA takes the stemmed query and does a similarity check (TFIDF search) to look for agents that are most likely to find services outlined in the query. The query is then forwarded to these selected agents from the multiagent system [9]."

"Service Oriented Multi-agent referral system for service lookup" this multi agent referral system is used for faster search. Here each time a service is created this service will select an agent and then that agent will connect himself into the referral community. Referral system is consists of

i) Agent Profile

ii) Neighbor Model

iii) Multi Agent model

iv) Service module

The client-server architecture [18] is proposed which can be connected through SOAP and XML protocols. One platform is used for server end and multiple for client. As learner uses different devices to access the system, an interface agent is introduced. Java is used to develop user interface. User agent is dependent on the user how it interacts with the server. User agent and web service based agent communicate through SOAP protocol is used. Web service based intelligent agents; database and educational services are the constituents of server side. Agents are communicated through web based service which provides more reliable communication. User profiles and other related data are accumulated in database. Agent provides user required information and newly services provided [18]. Based on the Java mobile agent technology [31] called aglet Service oriented agents system for networked e-learning is proposed. When a user sends a query, query analyzer agent checks other service agents. The selected service agent makes use of the recommendation characteristic built in to advance the research process. Service composition agent will get the results of search and ask user to select a required one. After selection user get the service. Query analyzer agent uses Term Frequency Inverse Document Frequency scheme to separate query words. The user interface contains a text file, dropdown list, and button and popup menu for providing and selecting query. The referral system consists of Agent Profile, Neighbor Model, Multi Agent Learning and Service module. Oak Ridge Mobile Agent Community (ORMAC) framework extension will be used for agent architecture [31].

Paper [22] proposed a study plan by e learning using content organization and a content push agent using corm based learning management system. In the system two agents have been designed for proper study management. User interface agent (UIA), which are used for interaction with user. It collects the useful information and feedback from user side. The other agent is content push agent (CPA). CPA explores suitable learning content from database and pushes it to the user side. For this agent push algorithm has been used for its functionality [22]. Students may learn according to teaching strategy and suitable content pushed towards user according to his requirement. So system provides personality learning contents for each learner [22].

[7] This paper is a multi-agent framework which base upon social entities which are playing their role in designing the e learning course. They play their firstly at the time of course designing, secondly when the course is designed they provide the feedback about the e learning design and content and this feedback will be immediate feedback after the student or any other person of society who is using the system when he/she attempting the task or question/answer he/she will give the feedback instead of delayed feedback.

This new 2-phase approach is very attractive. It has 2 layer supports for designers and assisting them two develop more and better design of e-learning content. The immediate feedback is available to course designers at regular basis so that they can make updates in the system as the user demanding while the delayed feedback is attached with the users 
are working with the system for long run time. The $\mathrm{x}$-students of their graduate schools are also the part of the framework; they can also suggest the new requirements for making e learning contents better. The multi agent framework will receive the feedback and perform the desire operations with the help of different agents which are interconnect.

CDs consist of:

1. Central Transaction Agent (CTA)

2. Concept Map Manager (CMM)

3. Relevant Term Extractor (RTE)

4. Feedback Manager and Prioritize (FMP

\section{Domain Ontology for Personalized Multi-agent e-Learning Systems}

In this paper [5] the author Paper introduce a domain ontology for describing learning material that is composed of a course capable of providing adaptive e learning style and related educational recourse .which improve the learning style of a user. System compares the user learning style with the educational recourses learning style possibilities. According to this compensate system only dispatch the learning material for the specified learner which would be the best fit according to his style, this is done on the basis of learning objects which possess a fine grain granularity for achieving a good reuse of resources [5].

In this paper [22] an exceptional representation of user quires has been introduced based on multi-agent system and domain ontology. The conceptual structure has been described into three portions.

1 exceptional design phase

2 exceptional development phases

3 exceptional results

Using this exceptional structure of the system the objective is to improve the search results of search engine in some meaningful pattern as contrast to search offered by yahoo or Google search engine. Which use basic search by word matching algorithms and present output in linear fashion based on text or hierarchy arrangements [22].

Table 1. Characteristics Chart for E-Learning Systems

\begin{tabular}{|c|c|c|c|c|c|c|c|c|c|}
\hline $\begin{array}{l}\text { Sr. } \\
\text { No. }\end{array}$ & $\begin{array}{l}\mathbf{Y} \\
\mathbf{e} \\
\mathbf{a} \\
\mathbf{r}\end{array}$ & $\begin{array}{l}\text { techniq } \\
\text { ue }\end{array}$ & $\begin{array}{l}\text { Communica } \\
\text { tion } \\
\text { protocol }\end{array}$ & $\begin{array}{l}\text { Teache } \\
\mathbf{r} \\
\text { based } \\
\text { assista } \\
\text { nce }\end{array}$ & $\begin{array}{l}\text { Studen } \\
t \text { based } \\
\text { assista } \\
\text { nce }\end{array}$ & advantages & Tool & $\begin{array}{l}\text { layer } \\
\text { ed }\end{array}$ & Comment \\
\hline [1] & $\begin{array}{l}2 \\
0 \\
0 \\
9\end{array}$ & $\begin{array}{l}\text { Intellige } \\
\text { nt black } \\
\text { board } \\
\text { agent }\end{array}$ & & yes & yes & $\begin{array}{l}\text { Provide content } \\
\text { exposition and } \\
\text { learning } \\
\text { strategy } \\
\text { planning }\end{array}$ & & No & $\begin{array}{l}\text { proposed } \\
\text { architecture } \\
\text { using the } \\
\text { SA- } \\
\text { RT/OPN } \\
\text { methodolo } \\
\text { gy and the } \\
\text { Object } \\
\text { Petri net } \\
\text { control }\end{array}$ \\
\hline [2] & $\begin{array}{l}2 \\
0 \\
0 \\
9\end{array}$ & $\begin{array}{l}\text { GENERI } \\
\text { C } \\
\text { Technol } \\
\text { ogy of } \\
\text { multi } \\
\text { agents }\end{array}$ & & Yes & yes & $\begin{array}{l}\text { It provide } \\
\text { interportabilty, } \\
\text { security, } \\
\text { accessibility in } \\
\text { one plait form }\end{array}$ & & yes & $\begin{array}{l}\text { Work on } \\
\text { distributed } \\
\text { heterogene } \\
\text { ous } \\
\text { environme } \\
\text { nt }\end{array}$ \\
\hline [3] & $\begin{array}{l}2 \\
0 \\
1 \\
0\end{array}$ & $\begin{array}{l}\text { Multiple } \\
\text { agent } \\
\text { layers }\end{array}$ & & yes & yes & $\begin{array}{l}\text { To achieve } \\
\text { intelligence, } \\
\text { distributed, } \\
\text { adaptive, } \\
\text { interaction, }\end{array}$ & & Yes & $\begin{array}{l}\text { work on } \\
\text { SCORM } \\
\text { for reuse } \\
\text { and sharing } \\
\text { of E- }\end{array}$ \\
\hline
\end{tabular}




\begin{tabular}{|c|c|c|c|c|c|c|c|c|c|}
\hline & & & & & & $\begin{array}{l}\text { accessibility, } \\
\text { personality, } \\
\text { security }\end{array}$ & & & $\begin{array}{l}\text { learning } \\
\text { contents }\end{array}$ \\
\hline [4] & $\begin{array}{l}2 \\
0 \\
1 \\
0\end{array}$ & $\begin{array}{l}\text { Data } \\
\text { mining }\end{array}$ & $\begin{array}{l}\text { Web } \\
\text { services }\end{array}$ & Yes & Yes & $\begin{array}{l}\text { work is a } \\
\text { step in the } \\
\text { direction of } \\
\text { bridging the } \\
\text { information } \\
\text { gap between an } \\
\text { e-learning and } \\
\text { an } \\
\text { (ABIS). }\end{array}$ & & No & $\begin{array}{l}\text { applicabilit } \\
\text { y of } \\
\text { Mining } \\
\text { techniques } \\
\text { to E- } \\
\text { learning } \\
\text { needs to be } \\
\text { done }\end{array}$ \\
\hline$[5]$ & $\begin{array}{l}2 \\
0 \\
0 \\
6\end{array}$ & $\begin{array}{l}\text { Ontolog } \\
\text { y based }\end{array}$ & $\begin{array}{l}\text { Web } \\
\text { ontology }\end{array}$ & No & yes & $\begin{array}{l}\text { To achieve } \\
\text { most } \\
\text { appropriate } \\
\text { learning style }\end{array}$ & & No & \\
\hline [6] & $\begin{array}{l}2 \\
0 \\
0 \\
7\end{array}$ & $\begin{array}{l}\text { Asynchr } \\
\text { onous } \\
\text { Backup } \\
\text { and } \\
\text { recovery }\end{array}$ & Client/server & No & Yes & $\begin{array}{l}\text { Provide backup } \\
\text { and recovry } \\
\text { scheme when } \\
\text { one node fail } \\
\text { another node } \\
\text { provide service }\end{array}$ & & & \\
\hline [7] & $\begin{array}{l}2 \\
0 \\
1 \\
1\end{array}$ & $\begin{array}{l}\text { Social } \\
\text { support } \\
\text { based } \\
\text { distincti } \\
\text { ve } \\
\text { multiage } \\
\text { nt } \\
\text { framewo } \\
\text { rk }\end{array}$ & $\begin{array}{l}\text { Web } \\
\text { services }\end{array}$ & No & Yes & $\begin{array}{l}\text { The system } \\
\text { employs Multi } \\
\text { Attribute } \\
\text { Utility } \\
\text { Technique } \\
\text { (MAUT) to } \\
\text { prioritize the } \\
\text { cumulative } \\
\text { feedback }\end{array}$ & & No & \\
\hline [8] & $\begin{array}{l}2 \\
0 \\
1 \\
1\end{array}$ & $\begin{array}{l}\text { Intellige } \\
\text { nt online } \\
\text { assesme } \\
\text { nt }\end{array}$ & $\begin{array}{l}\text { Web } \\
\text { services }\end{array}$ & No & Yes & $\begin{array}{l}\text { To improving } \\
\text { the } \\
\text { performance of } \\
\text { individual } \\
\text { learner }\end{array}$ & & No & $\begin{array}{l}\text { To work on } \\
\text { effective } \\
\text { learning } \\
\text { through } \\
\text { data } \\
\text { mining } \\
\end{array}$ \\
\hline \multicolumn{10}{|l|}{ [9] } \\
\hline [10] & $\begin{array}{l}2 \\
0 \\
1 \\
0\end{array}$ & $\begin{array}{l}\text { Integrate } \\
\text { d } \\
\text { Multiage } \\
\text { nt } \\
\text { technolo } \\
\text { gy }\end{array}$ & $\begin{array}{l}\text { Simple } \\
\text { Object } \\
\text { Access } \\
\text { Protocol and } \\
\text { XML }\end{array}$ & no & yes & $\begin{array}{l}\text { collaboration } \\
\text { and safe } \\
\text { resource } \\
\text { sharing }\end{array}$ & & & \\
\hline [11] & $\begin{array}{l}2 \\
0 \\
0 \\
6\end{array}$ & $\begin{array}{l}\text { Mobile } \\
\text { agent } \\
\text { technolo } \\
\text { gy }\end{array}$ & $\begin{array}{l}\text { TCP/IP,HTT } \\
\mathrm{P}\end{array}$ & yes & yes & $\begin{array}{l}\text { Individual user } \\
\text { content } \\
\text { composition, } \\
\text { rapid course } \\
\text { development } \\
\text { and } \\
\text { collaboration } \\
\end{array}$ & & & $\begin{array}{l}\text { Mobile } \\
\text { agent e- } \\
\text { learning } \\
\text { with } \\
\text { wireless } \\
\text { system }\end{array}$ \\
\hline [12] & $\begin{array}{l}2 \\
0 \\
0 \\
6\end{array}$ & $\begin{array}{l}\text { Multi- } \\
\text { Agent } \\
\text { Systems }\end{array}$ & & yes & yes & Group learning & $\begin{array}{l}\text { Jadex, } \\
\text { I*framework }^{*} \text { frame }\end{array}$ & & $\begin{array}{l}\text { Analyze } \\
\text { complex } \\
\text { scenarios, } \\
\text { more } \\
\text { intelligent } \\
\text { and } \\
\text { flexible. } \\
\end{array}$ \\
\hline [13] & $\begin{array}{l}2 \\
0 \\
0 \\
4\end{array}$ & $\begin{array}{l}\text { goal- } \\
\text { oriented } \\
\text { approach } \\
\text { (agent) }\end{array}$ & & no & yes & grid services & Globus toolkit & & $\begin{array}{l}\text { case } \\
\text { analysis } \\
\text { and } \\
\text { performanc } \\
\text { e } \\
\text { evaluation }\end{array}$ \\
\hline [14] & $\begin{array}{l}2 \\
0 \\
0 \\
4\end{array}$ & $\begin{array}{l}\text { Server/cl } \\
\text { ient } \\
\text { approach }\end{array}$ & $\begin{array}{l}\text { Internet } \\
\text { /intranet }\end{array}$ & no & yes & $\begin{array}{l}\text { to learner } \\
\text { profile and } \\
\text { multiple }\end{array}$ & $\begin{array}{l}\text { Automatic } \\
\text { Tutoring Tool } \\
\text { and the } \\
\text { Student } \\
\text { Evaluation } \\
\text { Tool, learner } \\
\text { profile tool }\end{array}$ & & $\begin{array}{l}\text { Implement } \\
\text { ed on } \\
\text { larger scale }\end{array}$ \\
\hline [15] & 2 & Multi- & & yes & yes & essential in the & BDI-ASPD & & complete \\
\hline
\end{tabular}




\begin{tabular}{|c|c|c|c|c|c|c|c|c|c|}
\hline & $\begin{array}{l}0 \\
0 \\
8\end{array}$ & $\begin{array}{l}\text { Agent } \\
\text { System } \\
\text { for } \\
\text { Collabor } \\
\text { ative E- } \\
\text { learning } \\
\text { (MASC } \\
\text { E). }\end{array}$ & & & & $\begin{array}{l}\text { educational } \\
\text { process, } \\
\text { information } \\
\text { gathering, } \\
\text { analysis and } \\
\text { distribution, } \\
\text { embedded } \\
\text { feedback, } \\
\text { assessment, } \\
\text { and } \\
\text { collaboration }\end{array}$ & & & $\begin{array}{l}\text { system } \\
\text { analysis }\end{array}$ \\
\hline [16] & $\begin{array}{l}2 \\
0 \\
0 \\
3\end{array}$ & $\begin{array}{l}\text { Multiage } \\
\text { nt } \\
\text { approach }\end{array}$ & & no & yes & $\begin{array}{l}\text { decision } \\
\text { making } \\
\text { learning }\end{array}$ & NEOCAMPS2 & & \\
\hline [17] & $\begin{array}{l}2 \\
0 \\
0 \\
6\end{array}$ & $\begin{array}{l}\text { ACM } \\
\text { CR } \\
\text { classific } \\
\text { ation } \\
\text { hierarch } \\
\text { y, Latent } \\
\text { Semanti } \\
\text { c } \\
\text { Analysis }\end{array}$ & $\begin{array}{l}\text { Agent } \\
\text { Transfer } \\
\text { Protocol } \\
\text { (ATP) }\end{array}$ & yes & yes & $\begin{array}{l}\text { self- } \\
\text { proclamation, } \\
\text { concept } \\
\text { relativity }\end{array}$ & & & \\
\hline & & & & & & & & & \\
\hline [18] & $\begin{array}{l}2 \\
0 \\
0 \\
5\end{array}$ & $\begin{array}{l}\text { multiage } \\
\text { nt } \\
\text { systems } \\
\text { and web } \\
\text { based(se } \\
\text { rver } \\
\text { client) }\end{array}$ & $\begin{array}{l}\text { SOAP, } \\
\text { XML, } \\
\text { WSDL, } \\
\text { UDDI }\end{array}$ & no & yes & $\begin{array}{l}\text { Interoperability } \\
\text {, Scalability, } \\
\text { Maintainability } \\
\text {, Flexibility, } \\
\text { Customization, } \\
\text { Interactivity }\end{array}$ & $\begin{array}{l}\text { JAVA } \\
\text { platform }\end{array}$ & & \\
\hline [19] & $\begin{array}{l}2 \\
0 \\
1 \\
0\end{array}$ & $\begin{array}{l}\text { Online } \\
\text { intellige } \\
\mathrm{nt} \\
\text { toutoring }\end{array}$ & $\begin{array}{l}\text { Web } \\
\text { services }\end{array}$ & No & Yes & $\begin{array}{l}\text { To support } \\
\text { flexible } \\
\text { teaching } \\
\text { learning activty }\end{array}$ & $\begin{array}{l}\text { Java, MySQL } \\
\text { and } \\
\text { Java Server } \\
\text { Faces (JSF). }\end{array}$ & No & $\begin{array}{l}\text { To work on } \\
\text { intelligent } \\
\text { middleware } \\
\text { and } \\
\text { ontology } \\
\text { content } \\
\text { features }\end{array}$ \\
\hline [20] & $\begin{array}{l}2 \\
0 \\
0 \\
9\end{array}$ & $\begin{array}{l}\text { E } \\
\text { learning } \\
\text { using } \\
\text { web } \\
\text { services }\end{array}$ & $\begin{array}{l}\text { SOAP, } \\
\text { XML, } \\
\text { WSDL, } \\
\text { UDDI }\end{array}$ & No & Yes & $\begin{array}{l}\text { Provide } \\
\text { integration,flex } \\
\text { ibilty and light } \\
\text { weight system. }\end{array}$ & & No & $\begin{array}{l}\text { To design } \\
\text { system for } \\
\text { comunicati } \\
\text { on between } \\
\text { agent and } \\
\text { services } \\
\end{array}$ \\
\hline [21] & $\begin{array}{l}2 \\
0 \\
0 \\
9\end{array}$ & $\begin{array}{l}\text { Intellige } \\
\text { nt black } \\
\text { board } \\
\text { agent }\end{array}$ & & yes & yes & $\begin{array}{l}\text { Provide content } \\
\text { exposition and } \\
\text { learning } \\
\text { strategy } \\
\text { planning }\end{array}$ & & No & $\begin{array}{l}\text { proposed } \\
\text { architecture } \\
\text { using the } \\
\text { SA- } \\
\text { RT/OPN } \\
\text { methodolo } \\
\text { gy and the } \\
\text { Object } \\
\text { Petri net } \\
\text { control }\end{array}$ \\
\hline [22] & $\begin{array}{l}2 \\
0 \\
0 \\
8\end{array}$ & $\begin{array}{l}\text { Intellige } \\
\text { nt } \\
\text { content } \\
\text { push for } \\
\text { scorm } \\
\text { based } \\
\end{array}$ & & Yes & Yes & & $\begin{array}{l}\text {.net/sql/oracle/ } \\
\text { FIPA }\end{array}$ & No & \\
\hline [23] & $\begin{array}{l}2 \\
0 \\
0 \\
7\end{array}$ & $\begin{array}{l}\text { Adoptiv } \\
\text { e e } \\
\text { learning }\end{array}$ & XML, & Yes & Yes & $\begin{array}{l}\text { Partition } \\
\text { students into } \\
\text { clusters and } \\
\text { graphs. } \\
\end{array}$ & JADE/LEAP & No & $\begin{array}{l}\text { To work on } \\
\text { further } \\
\text { analytical } \\
\text { study }\end{array}$ \\
\hline [24] & $\begin{array}{l}2 \\
0 \\
1 \\
0\end{array}$ & $\begin{array}{l}\text { Domain } \\
\text { ontology } \\
\text { based } \\
\text { system }\end{array}$ & $\begin{array}{l}\text { Domain } \\
\text { ontology } \\
\text { representatio } \\
\mathrm{n}\end{array}$ & Yes & yes & $\begin{array}{l}\text { exceptional } \\
\text { representation } \\
\text { of user queries } \\
\text { based on multi } \\
\text { gent } \\
\text { system and } \\
\text { domain } \\
\text { ontology }\end{array}$ & $\begin{array}{l}\text { MAS and jena } \\
\text { framework }\end{array}$ & No & \\
\hline
\end{tabular}




\begin{tabular}{|c|c|c|c|c|c|c|c|c|c|}
\hline [25] & $\begin{array}{l}2 \\
0 \\
0 \\
9 \\
\end{array}$ & $\begin{array}{l}\text { Integrate } \\
\text { technolo } \\
\text { gy }\end{array}$ & $\begin{array}{l}\text { DTS(data } \\
\text { transfer } \\
\text { system) } \\
\text { Web Server } \\
\end{array}$ & Yes & yes & $\begin{array}{l}\text { Integrate } \\
\text { system with } \\
\text { DWH and data } \\
\text { mining }\end{array}$ & & No & $\begin{array}{l}\text { Handle } \\
\text { chalange of } \\
\text { self } \\
\text { learning }\end{array}$ \\
\hline [26] & $\begin{array}{l}2 \\
0 \\
0 \\
9\end{array}$ & $\begin{array}{l}\text { GENERI } \\
\text { C } \\
\text { Technol } \\
\text { ogy of } \\
\text { multi } \\
\text { agents }\end{array}$ & & Yes & yes & $\begin{array}{l}\text { It provide } \\
\text { interportabilty, } \\
\text { security, } \\
\text { accessibility in } \\
\text { one plait form }\end{array}$ & & yes & $\begin{array}{l}\text { Work on } \\
\text { distributed } \\
\text { heterogene } \\
\text { ous } \\
\text { environme } \\
\text { nt }\end{array}$ \\
\hline [27] & $\begin{array}{l}2 \\
0 \\
0 \\
8\end{array}$ & $\begin{array}{l}\text { Inclusive } \\
\mathrm{e} \\
\text { learning }\end{array}$ & & No & Yes & $\begin{array}{l}\text { Provide } \\
\text { personalization } \\
\text { and inclusive e } \\
\text { learning }\end{array}$ & & No & $\begin{array}{l}\text { Next } \\
\text { implementa } \\
\text { tion of both } \\
\text { A2M and } \\
\text { ADA+ }\end{array}$ \\
\hline [28] & $\begin{array}{l}2 \\
0 \\
0 \\
8\end{array}$ & $\begin{array}{l}\text { Mutual } \\
\text { model } \\
\text { using } \\
\text { multi } \\
\text { agent }\end{array}$ & $\begin{array}{l}\text { (ACL)Agent } \\
\text { communicati } \\
\text { on language }\end{array}$ & Yes & Yes & $\begin{array}{l}\text { Improve } \\
\text { system internal } \\
\text { process to } \\
\text { provide } \\
\text { personal and } \\
\text { adoptive } \\
\text { learning } \\
\end{array}$ & Jade & No & $\begin{array}{l}\text { Will be } \\
\text { work on } \\
\text { distributed } \\
\text { environme } \\
\text { nt using } \\
\text { mutual } \\
\text { model }\end{array}$ \\
\hline \multicolumn{10}{|l|}{ [29] } \\
\hline [30] & $\begin{array}{l}2 \\
0 \\
1 \\
0\end{array}$ & $\begin{array}{l}\text { Prometh } \\
\text { eus } \\
\text { methodo } \\
\text { logy }\end{array}$ & & yes & yes & $\begin{array}{l}\text { pedagogic, } \\
\text { social and } \\
\text { economic }\end{array}$ & $\begin{array}{l}\text { JACK } \\
\text { platform }\end{array}$ & & \\
\hline [31] & $\begin{array}{l}2 \\
0 \\
0 \\
9\end{array}$ & $\begin{array}{l}\text { aglet } \\
\text { Service } \\
\text { oriented } \\
\text { agents } \\
\text { system } \\
\text { (Java } \\
\text { mobile } \\
\text { agent } \\
\text { technolo } \\
\text { gy) }\end{array}$ & & yes & yes & $\begin{array}{l}\text { effective and } \\
\text { efficient } \\
\text { communication }\end{array}$ & $\begin{array}{l}\text { Oak Ridge } \\
\text { Mobile Agent } \\
\text { Community } \\
\text { (ORMAC) } \\
\text { framework }\end{array}$ & & \\
\hline [32] & $\begin{array}{l}2 \\
0 \\
0 \\
8\end{array}$ & $\begin{array}{l}\text { Regional } \\
\text { ly } \\
\text { Distribut } \\
\text { ed } \\
\text { Architec } \\
\text { ture for } \\
\text { Dynamic } \\
\text { e- } \\
\text { Learning } \\
\text { Environ } \\
\text { ment }\end{array}$ & & yes & yes & $\begin{array}{l}\text { independence, } \\
\text { communication } \\
\text {, and } \\
\text { consistency }\end{array}$ & JADE & & $\begin{array}{l}\text { incorporati } \\
\text { ng OGSA- } \\
\text { DI } \\
\text { producing } \\
\text { grid } \\
\text { services, } \\
\text { refining } \\
\text { search } \\
\text { result }\end{array}$ \\
\hline [34] & $\begin{array}{l}2 \\
0 \\
0 \\
8\end{array}$ & $\begin{array}{l}\text { Rough } \\
\text { set } \\
\text { theory is } \\
\text { combine } \\
\mathrm{d} \text { with } \\
\text { mutual } \\
\text { learning }\end{array}$ & & yes & yes & $\begin{array}{l}\text { rationality, } \\
\text { feasibility and } \\
\text { validity }\end{array}$ & $\begin{array}{l}\text { NJUT frame } \\
\text { work }\end{array}$ & & $\begin{array}{l}\text { intelligenti } \\
\text { ze } \\
\text { problems } \\
\text { of } \\
\text { collaborati } \\
\text { ve learning }\end{array}$ \\
\hline [35] & $\begin{array}{l}2 \\
0 \\
0 \\
7\end{array}$ & $\begin{array}{l}\text { agent- } \\
\text { based } \\
\text { concept } \\
\text { client } \\
\text { server } \\
\end{array}$ & & no & yes & $\begin{array}{l}\text { asynchronous } \\
\text { distance } \\
\text { learning }\end{array}$ & & & \\
\hline [36] & $\begin{array}{l}2 \\
0 \\
0 \\
7\end{array}$ & $\begin{array}{l}\text { Peer-to- } \\
\text { peer } \\
\text { based } \\
\text { network }\end{array}$ & p2p network & no & yes & $\begin{array}{l}\text { affective } \\
\text { communication } \\
\text { in virtual } \\
\text { system, } \\
\text { expression } \\
\text { based } \\
\text { evaluation } \\
\end{array}$ & $\begin{array}{l}\text { EMASPEL } \\
\text { Framework } \\
\text { with MadKit }\end{array}$ & & $\begin{array}{l}\text { Integrate } \\
\text { the peer-to- } \\
\text { peer based } \\
\text { network } \\
\text { platform } \\
\text { into grid } \\
\text { system } \\
\end{array}$ \\
\hline [37] & $\begin{array}{l}2 \\
0 \\
0 \\
7\end{array}$ & $\begin{array}{l}\text { Service } \\
\text { based } \\
\text { multi } \\
\text { agents }\end{array}$ & & yes & yes & Search module & Jade & & \\
\hline
\end{tabular}




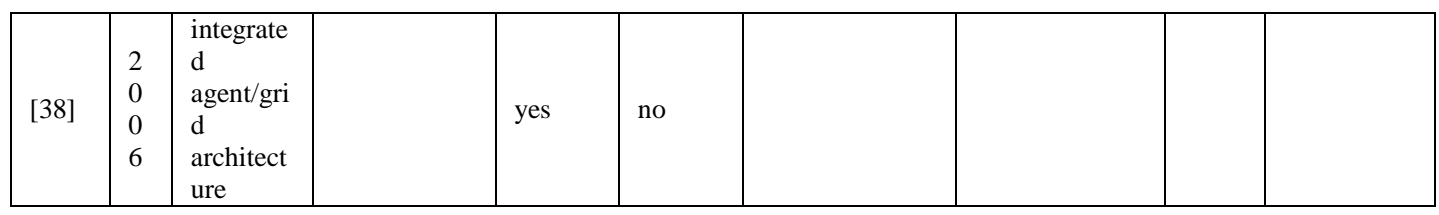

\section{Conclusion}

Learning is an active process of constructing and sharing the knowledge among others. This paper provided a Survey on Intelligent Agent Based Architecture For E-Learning System which include features like interoperable, distributed, adaptive, agent based, ontology based, collaborative and intelligence, if the architecture includes semantic web technology data mining techniques like clustering and classification techniques and appropriate levels of security, the system will be more efficient reliable and user friendly.

\section{References}

[1] S. Hammami, H. Mathkour and E. A. Al-Mosallam, "A multi-agent architecture for adaptive E-learning systems using a blackboard agent", Computer Science and Information Technology, (2009), pp. 184-188.

[2] K. Sakthiyavathi and K. Palanivel, "A generic architecture for agent based E-learning system", In Intelligent Agent \& Multi-Agent Systems, IAMA International Conference on IEEE, (2009) July, pp. 15.

[3] A. P. Ali, H. Dehghan and J. Gholampour, "An agent based multilayered architecture for e-learning system", In E-Learning and E-Teaching (ICELET), Second International Conference on IEEE, (2010) December, pp. 22-26.

[4] P. Fournier-Viger, R. Nkambou and V. S. M. Tseng, "RuleGrowth: mining sequential rules common to several sequences by pattern-growth", In Proceedings of the 2011 ACM symposium on applied computing, ACM, (2011) March, pp. 956-961.

[5] J. M. Gascueña, A. Fernandez-Caballero and P. Gonzalez, "Domain Ontology for Personalized ELearning in Educational Systems", In ICALT, (2006) July, pp. 456-458.

[6] T. Kawamura, K. Sugahara, S. Kinoshita, R. Nakatani and S. Motomura, "Backup and recovery scheme for multi-agent-based e-learning system", In Integration of Knowledge Intensive Multi-Agent Systems, KIMAS, International Conference on IEEE, (2007) April, pp. 73-78.

[7] R. Sharma, H. Banati and P. Bedi, "Social support based multi-agent framework for designing an elearning course", In Communication Software and Networks (ICCSN), 2011 IEEE 3rd International Conference on IEEE, (2011) May, pp. 160-164.

[8] M. U. Kumar, J. Mamatha, S. Jain and D. K. Jain, "Intelligent online assessment methodology", In Next Generation Web Services Practices (NWeSP)", 2011 7th International Conference on IEEE, (2011) October, pp. 215-220.

[9] N. Hussain and M. K. Khan, "Service-oriented e-learning architecture using web service-based intelligent agents", In Information and Communication Technologies, 2005. ICICT 2005. First International Conference on IEEE, (2005) August, pp. 137-143.

[10] X. Li, "A study on e-learning systems integration based on multi-agent technology", In Education Technology and Computer (ICETC), 2010 2nd International Conference on IEEE, vol. 1, (2010) June, pp. V1-294).

[11] H. Al-Sakran, "An agent-based architecture for developing e-learning system”, Information Technology Journal, vol. 5, no. 1, (2006), pp. 121-127.

[12] Z. Liu, H. Jin and Z. Fang, "Collaborative learning in e-learning based on multi-agent systems", In Computer Supported Cooperative Work in Design, 2006. CSCWD'06. 10th International Conference on IEEE, (2006) May, pp. 1-5.

[13] Z. Q. Shen, R. Gay, C. Y. Miao and Q. Wang, "Goal oriented modeling for agent mediated e-learning grid", In Control, Automation, Robotics and Vision Conference, 2004. ICARCV $20048^{\text {th }}$, IEEE, vol. 3, (2004) December, pp. 2280-2285.

[14] P. D. Cristea and R. Tuduce, "Intelligent e-learning environments architecture and basic tools", In Information Technology Based Higher Education and Training, ITHET Proceedings of the FIfth International Conference on IEEE, (2004) June, pp. 610-615.

[15] H. Mahdi and S. S. Attia, "MASCE: a multi-agent system for collaborative e-learning", In Computer Systems and Applications, 2008. AICCSA 2008. IEEE/ACS International Conference on IEEE, (2008) March, pp. 925-926.

[16] F. De Arriaga, M. El Alami and A. Arriaga, "Multi-agent architecture for intelligent E-learning", In Electronics, Circuits and Systems, ICECS, Proceedings of the 2003 10th IEEE International Conference on, vol. 3, (2003) December, pp. 1228-1231. 
[17] R. Ponnusamy and T. V. Gopal, "A user-adaptive self-proclamative multi-agent based recommendation system design for e-learning digital libraries", In Cybernetics and Intelligent Systems, IEEE Conference on, (2006) June, pp. 1-7.

[18] N. Hussain and M. K. Khan, "Service-oriented e-learning architecture using web service-based intelligent agents", In Information and Communication Technologies, ICICT, First International Conference on IEEE, (2005) August, pp. 137-143.

[19] J. N. Liu, Y. Wang, L. Jia, S. Shiu, Z. Li and Y. Rao, "Poly-X: An online intelligent tutoring system for e-learning", In Data Mining and Intelligent Information Technology Applications (ICMiA), 3rd International Conference on IEEE, (20011) October, pp. 204-209.

[20] X. Wei and J. Yan, "An e learning system architecture based on web service intelligence agents".

[21] S. Hammami, H. Mathkour and E. A. Al-Mosallam, "A multi-agent architecture for adaptive E-learning systems using a blackboard agent”, Computer Science and Information Technology, (2009), pp. 184-188.

[22] Y. Peng, "Intelligent content push for SCORM-based e-learning systems", In Intelligent Information Technology Application Workshops, IITAW'08, International Symposium on IEEE, (2008) December, pp. 239-242.

[23] S. Garruzzo, D. R. Giuseppe, M. L. Sarn’e, “A multiagent system for supporting adaptive e learning system".

[24] A. S. Hosam, M. Abbas and I. Naufal, "The design and development of exceptional representation based on domain ontology and multi-agent systems for e-learning purposes”, In Mathematical/Analytical Modelling and Computer Simulation (AMS), Fourth Asia International Conference on IEEE, (2010) May, pp. 517-520.

[25] G. Chen, "The research on architecture of intelligent E-learning system", In Computer Science \& Education, ICCSE'09, 4th International Conference on IEEE, (2009) July, pp. 1079-1081.

[26] K. Sakthiyavathi and K. Palanivel, "A generic architecture for agent based E-learning system", In Intelligent Agent \& Multi-Agent Systems, IAMA, International Conference on IEEE, (2009) July, pp. 15 .

[27] O. C. Santos and J. G. Boticario, "Intellegent support for inclusive e learning system".

[28] T. Chen, "Mutual Model of Multiagent Process in E-learning Architecture", In Information Science and Engineering, 2008. ISISE'08. International Symposium on IEEE, (2008) December, vol. 2, pp. 154-158.

[29] X. Li, "A study on e-learning systems integration based on multi-agent technology", In Education Technology and Computer (ICETC), 2010 2nd International Conference on IEEE, (2010) June, vol. 1, pp. V1-294.

[30] C. Zhang, Z. Xu, W. Li and S. Zhen, "Design and implementation on e-learning environment based on agent", In 2010 International Conference on Computer, Mechatronics, Control and Electronic Engineering, vol. 6, (2010), pp. 435-438.

[31] T. Chellatamilan and R. M. Suresh, "Service Oriented Intelligent Agents for E-Learning Systems", TECHNIA - International Journal of Computing Science and Communication Technologies, vol. 2, no. 1 , (2009) July.

[32] S. AlZahrani, A. Ayesh and H. Zedan, "Multi-agent system based regional data grid", In Computer Engineering \& Systems, 2008. ICCES 2008. International Conference on IEEE, (2008) November, pp. 337-342.

[33] H. Mahdi and S. S. Attia, "MASCE: a multi-agent system for collaborative e-learning", In Computer Systems and Applications, 2008. AICCSA 2008. IEEE/ACS International Conference on IEEE, (2008) March, pp. 925-926.

[34] P. Fang and P. Yu, "Collaborative learning grouping problem in multi-agent e-learning based on rough set”, In 2008 International Conference on Computer Science and Software Engineering, vol. 5, (2008), pp. 174-177.

[35] K. J. Wang, "An agent-based prototype of asynchronous distance e-learning system for facilities planning courses", In Computational Science and its Applications, 2007. ICCSA 2007. International Conference on IEEE, (2007) August, pp. 176-184.

[36] M. Neji and M. B. Ammar, "Agent-based collaborative affective e-learning framework", The Electronic Journal of e-Learning, vol. 5, no. 2, (2007), pp. 123-134.

[37] T. Orzechowski, "The use of multi-agents' systems in e-learning platforms", In Control and Communications, SIBCON'07, Siberian Conference on IEEE, (2007) April, pp. 64-71.

[38] R. D. Andreev and N. V. Troyanova, "E-learning design: An integrated agent-grid service architecture", In Modern Computing, JVA'06, John Vincent Atanasoff 2006 International Symposium on IEEE, (2006) October, pp. 208-213.

[39] M. Arif, M. Illahi, A. Karim, S. Shamshirband, K. A. Alam, S. Farid and V. E. Balas, "An architecture of agent-based multi-layer interactive e-learning and e-testing platform”, Quality \& Quantity, (2014), pp. 124. 


\section{Authors}

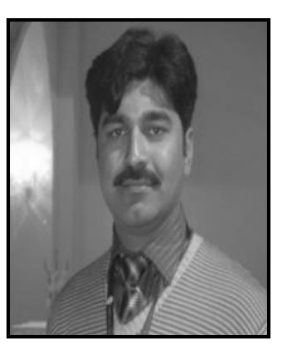

Muhammad Arif, he is a PhD student at Faculty of CS and IT, University of Malaya. Currently he is working on Medical image Processing. His research interests include image processing, E learning, Artificial intelligence and data mining. He joined UM as a Bright Spark Scholar in September 2013 for the period of 3 years. Before this he completed masters and bachelor degrees in Pakistan. $\mathrm{He}$ received his BS degree in Computer Science from University of Sargodha, Pakistan in 2011. He obtained his MS degree in Computer Science from COMSATS Islamabad 2013 Pakistan.

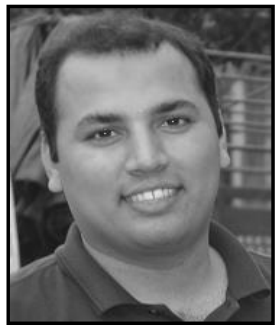

Mehdi Hussain, he is a Ph.D. candidate at Faculty of Computer Science and Information Technology, University of Malaya, under Faculty development program of National University of Science and Technology (NUST) Islamabad, Pakistan. He received Master and Bachelor of Computer Science degree from SZABIST (2011) and IUB (2005) Pakistan respectively. He served as senior software engineer in Streaming Networks Pvt. (Software House 2006-2014). Research interests are multimedia security, steganography, and data mining. He can be reached at mehdi141@ @otmail.com. 
International Journal of $u-$ and e- Service, Science and Technology Vol.8, No. 6 (2015) 